\title{
Microcystin-LR Detected in a Low Molecular Weight Fraction from a Crude Extract of Zoanthus sociatus
}

\author{
Dany Domínguez-Pérez 1,2, Armando Alexei Rodríguez ${ }^{3}$, Hugo Osorio 4,5,6, Joana Azevedo ${ }^{1}$, \\ Olga Castañeda ${ }^{7}$, Vítor Vasconcelos ${ }^{1,2}$ and Agostinho Antunes 1,2,* \\ 1 CIIMAR/CIMAR, Interdisciplinary Centre of Marine and Environmental Research, University of Porto, \\ Terminal de Cruzeiros do Porto de Leixões, Av. General Norton de Matos, s/n, 4450-208 Porto, Portugal; \\ danydguezperez@gmail.com (D.D.-P.); joana_passo@hotmail.com (J.A.); vmvascon@fc.up.pt (V.V.) \\ 2 Department of Biology, Faculty of Sciences, University of Porto, Rua do Campo Alegre, s/n, \\ 4169-007 Porto, Portugal \\ 3 Department of Experimental and Clinical Peptide Chemistry, Hanover Medical School (MHH), \\ Feodor-Lynen-Straße 31, D-30625 Hannover, Germany; aara259@gmail.com \\ 4 i3S - Instituto de Investigação e Inovação em Saúde, Universidade do Porto, Rua Alfredo Allen, 208, \\ 4200-135 Porto, Portugal; hosorio@ipatimup.pt \\ 5 Ipatimup, Institute of Molecular Pathology and Immunology of the University of Porto, \\ Rua Júlio Amaral de Carvalho, 45, 4200-135 Porto, Portugal \\ 6 Department of Pathology and Oncology, Faculty of Medicine, University of Porto, \\ Al. Prof. Hernâni Monteiro, 4200-319 Porto, Portugal \\ 7 Faculty of Biology, University of La Habana, 25 St 455, CP 10400 La Habana, Cuba; \\ castañedapasaron@gmail.com \\ * Correspondence: aantunes@ciimar.up.pt; Tel.: +353-22-340-1813
}

Academic Editor: Michio Murata

Received: 21 October 2016; Accepted: 20 February 2017; Published: 1 March 2017

\begin{abstract}
Cnidarian constitutes a great source of bioactive compounds. However, research involving peptides from organisms belonging to the order Zoanthidea has received very little attention, contrasting to the numerous studies of the order Actiniaria, from which hundreds of toxic peptides and proteins have been reported. In this work, we performed a mass spectrometry analysis of a low molecular weight (LMW) fraction previously reported as lethal to mice. The low molecular weight (LMW) fraction was obtained by gel filtration of a Zoanthus sociatus (order Zoanthidea) crude extract with a Sephadex G-50, and then analyzed by matrix-assisted laser desorption/ionization time-of-flight/time-of-flight (MALDI-TOF/TOF) mass spectrometry (MS) in positive ion reflector mode from $\mathrm{m} / z 700$ to $\mathrm{m} / \mathrm{z} 4000$. Afterwards, some of the most intense and representative MS ions were fragmented by MS/MS with no significant results obtained by Protein Pilot protein identification software and the Mascot algorithm search. However, microcystin masses were detected by mass-matching against libraries of non-ribosomal peptide database (NORINE). Subsequent reversed-phase C18 HPLC (in isocratic elution mode) and mass spectrometry analyses corroborated the presence of the cyanotoxin Microcystin-LR (MC-LR). To the best of our knowledge, this finding constitutes the first report of MC-LR in Z. sociatus, and one of the few evidences of such cyanotoxin in cnidarians.
\end{abstract}

Keywords: microcystins; MC-LR; Zoanthus sociatus; zoanthidea; cnidarian; Sephadex G50; MALDI-TOF/TOF

\section{Introduction}

Cnidarians represent promising sources of bioactive compounds, which can be of major pharmacological [1] and therapeutic interest [2-4]. However, many organisms belonging to the order Actiniaria (sea anemones), of the class Anthozoa, have been so far studied [5-8]. In contrast, the 
order Zoanthidea has been scarcely explored for biologically active compounds, although some potent non-peptide toxins, such as palytoxin and its analogues, have been characterized from this order [9-11]. Additionally, a peptide exhibiting a reversible delay of tetrodotoxin (TTX)-sensitive sodium channel inactivation, was isolated and characterized from Palythoa caribaeorum exudate, but its sequence does not resemble any cnidarian toxin previously reported [12]. In another study the exudate of $P$. caribaeourum provoked reversible delay of the inactivation process of voltage-gated sodium channels $\left(\mathrm{Na}_{\mathrm{V}} 1.7\right)$, inhibited voltage-gated calcium $\left(\mathrm{Ca}_{\mathrm{V}} 2.2\right)$ and delayed rectifier $\left(\mathrm{I}_{\mathrm{DR}}\right)$ currents of $\mathrm{K}_{\mathrm{V}}$ channels from rat superior cervical ganglion (SCG) neurons [12]. The matrix-assisted laser desorption/ionization time-of-flight/time-of-flight (MALDI-TOF/TOF) mass spectrometry (MS) analyses provided evidence of low molecular weight peptides involved in such effects on ion channels. It is also noteworthy the transcriptomic analysis on Protopalythoa variabilis, at which a transcript encoded a toxin called ShK/Aurelin-like that was toxic to zebrafish embryos [13].

Zoanthus sociatus also belongs to the order Zoanthidea. To date, few chemical studies have been reported from this organism, comprising the isolation and characterization of small non-proteinaceous molecules, such as the sterol zoanthosterol [14], as well as the norzoanthamines alkaloids and their analogues $[15,16]$. In addition to these bioactive compounds, an antifilarial activity from the Z. sociatus chloroform/methanol extract was reported [17]. Moreover, only two reports on the toxicity of the crude extract and semi-pure chromatographic fractions have been published. The first study demonstrated that Z. sociatus components below $7 \mathrm{kDa}$ are responsible for the inhibition of insulin secretion mediated by $\mathrm{Ca}^{2+}$ influx blockade in isolated rat $\beta$ cells [18]. A further study showed the biological evaluation of a low molecular weight (LMW) Sephadex G-50-chromatographic fraction lethal to mice, presumably by cardiorespiratory arrest [19].

Information provided in previous studies about the molecular mass profile of the low molecular weight (LMW) fraction from Z. sociatus showed components in the $m / z$ range from 700 to 6000 [18,19]. Nonetheless, the mass spectrometry analysis of a LMW fraction obtained by the same methodology showed many $m / z$ signals below 1000 [19]. Yet, the identification of the main components of the fraction remains to be done, thus, our main goal being the MALDI-TOF/TOF mass spectrometry analysis to characterize the most significant components of a LMW fraction from Z. sociatus. First, we performed the acquisition of a MALDI-TOF/TOF MS spectrum of the LMW fraction followed by MS/MS fragmentation of the most significant signals. In general, the obtained data did not allow the identification of sea anemones-like peptide toxins or linear peptides using the Protein Pilot protein identification software or the Mascot algorithm search [20].

On the other hand, $m / z$ signals from known cyanotoxins were detected by mass-matching against libraries of non-ribosomal peptide database (NORINE) [21,22]. Indeed, within the microcystins masses detected, the $m / z 995.53$ matched the expected $m / z$ signal for microcystin-LR (MC-LR). The presence of MC-LR was further demonstrated by high-resolution mass spectrometry analysis. While microcystins are recognized as freshwater cyanobacterial toxins, the occurrence of microcystins in marine ecosystems is not an isolated fact [23-27]. However, our findings constitute one of the few evidence of such cyanotoxin detected in cnidarians [28], and to the best of our knowledge the first report in Z. sociatus. Additionally, this work calls for further attention to the probabilities of water and food contamination by microcystins in tropical regions.

\section{Results and Discussion}

\subsection{Gel Filtration in Sephadex G-50}

The first purification step of the Z. sociatus crude extract was achieved by fractionation on Sephadex G-50. As previously described, the gel filtration chromatogram was divided into four fractions [19]. The resulting chromatogram showed the same elution profile of Z. sociatus crude extract, obtained by a similar purification protocol on HiLoad 16/20 Superdex 75 column [18]. The third 
fraction, called Zs G50-III, was then submitted to MALDI-TOF/TOF mass spectrometry analysis, given its lethal effect on mice as previously reported [19].

\subsection{Zs G50-III MALDI-TOF/TOF Analysis}

The selected fraction Zs G50-III was analyzed by MALDI-TOF/TOF MS analysis in positive ion reflector mode in the $m / z$ range from 700 to 4000 . The most intense signal detected in the MALDI-TOF/TOF MS analysis corresponded to $m / z$ values below 2000, resulting in the detection of 142 signals, ranging from $m / z 703.93$ to 1336.96 . The highest intensity signals are shown in Figure 1 . Afterwards, some of the most intense and representative MS ions corresponding to $m / z 876.98,861.01$, 1050.04, and 1066.00 were fragmented by MS/MS (Figures 2 and 3). Then, all the data generated by the MALDI-TOF/TOF procedure were submitted to search with the Mascot (Matrix-Science, London, UK) algorithm against UniProtKB protein sequence database [29], specifically in the Metazoan and Cnidaria section. Additionally, the spectra were also analyzed with the Protein Pilot protein identification software v4.5 (AB SCIEX). No significant result was obtained by any of the mentioned methods. The fragmentation pattern of the selected ions showed scarce peaks. In fact, the spectra do not resemble those of linear peptides, but seem to be related to cyclo-peptides fragmentation.

On the other hand, cyanotoxins-related masses were detected by peak list mass-matching against libraries of non-ribosomal peptide database (NORINE). Indeed, some of the most intense signals were related to microcystins. The mass $\mathrm{m} / \mathrm{z} 1066.00$ matched a reported microcystin [9-acetyl-Adda5]MC-RR [30]. Furthermore, the MS/MS analyses of $m / z 1066.00$ showed a high intensity signal at $m / z 876.94$ (Figure 2). Besides, in the MS/MS spectra of $m / z 1066.00$ and $m / z 876.94$ signals at $m / z$ 265.95 and 627.05, were detected, respectively (Figure 2). These masses were previously found in the LC/ESI-Q-ToF-MS/MS spectrum of the microcystin [9-acetyl-Adda5]-MC-RR [30]. Other important diagnostic signals such as $m / z 135$ corresponding to 3-amino-9-methoxy-2,6,8-trimethyl-10-phenyldeca-4,6-dienoic acid (Adda) fragment, or $m / z 163$ corresponding to acetyl-Adda side chain were absent or could not be detected because of their low intensity.

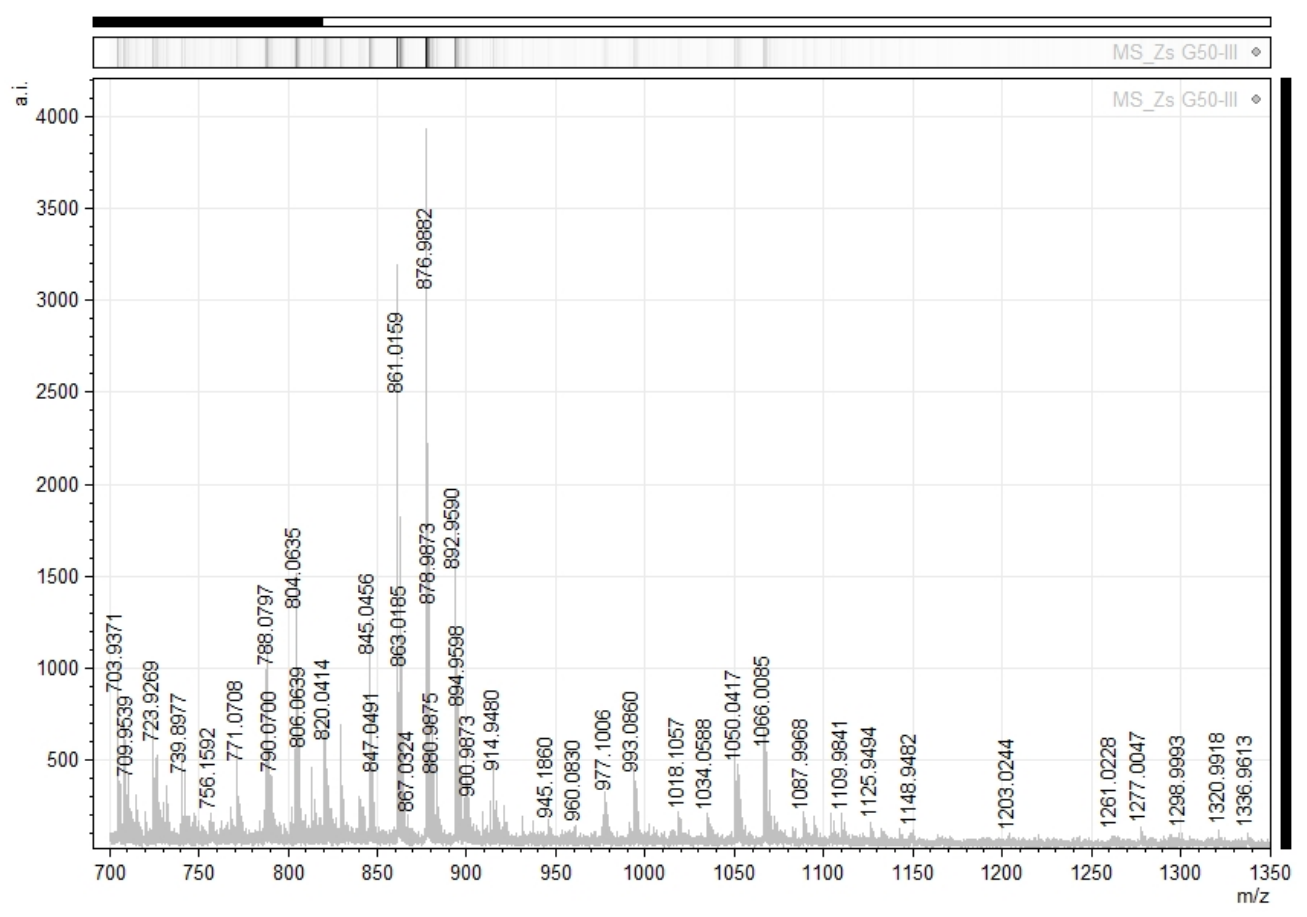

Figure 1. Matrix-assisted laser desorption/ionization time-of-flight/time-of-flight (MALDI-TOF) mass spectrum of the Sephadex G-50 fraction called Zs G50-III. The mass spectrum shows absolute ion intensity (a.i) versus mass-to-charge ratio $(\mathrm{m} / \mathrm{z})$ of Zs G50-III components for the mass range $\mathrm{m} / \mathrm{z} 700$ to 1350 . 


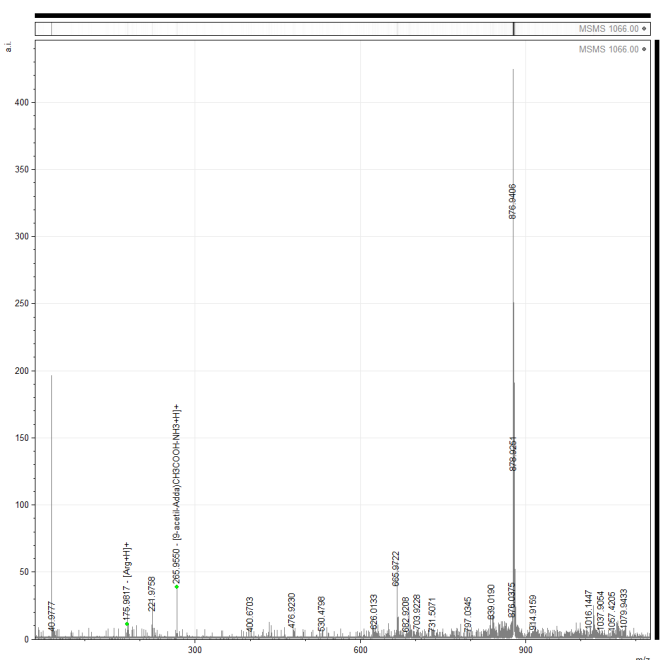

(a)

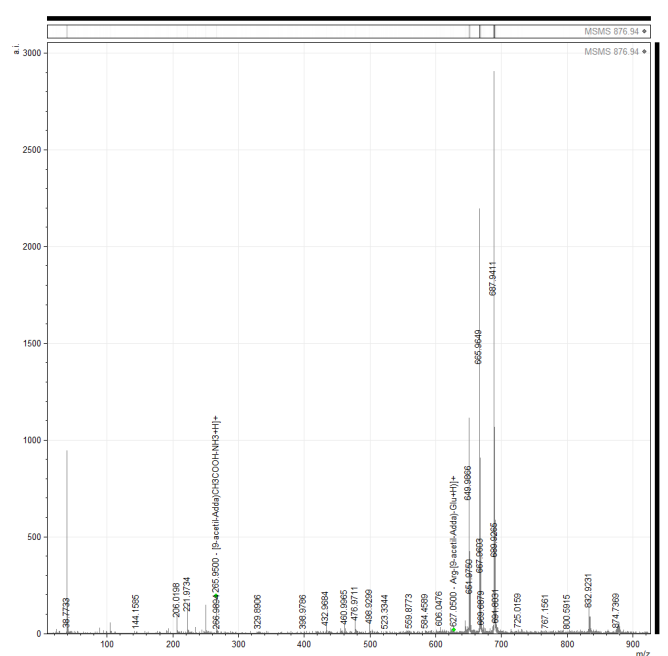

(b)

Figure 2. Matrix-assisted laser desorption/ionization time-of-flight/time-of-flight (MALDI-TOF/TOF) mass-spectra of two peaks of interest from fraction Zs G50-III. (a) Analysis of $m / z 1066.00$ is shown, highlighting the intense signal at $m / z$ 876.94; and (b) analysis of the $m / z$ 876.94. This signal occurred in the MALDI-TOF/TOF spectrum of $m / z$ 1066.00, but another signal was also identified at $m / z$ 265.95.

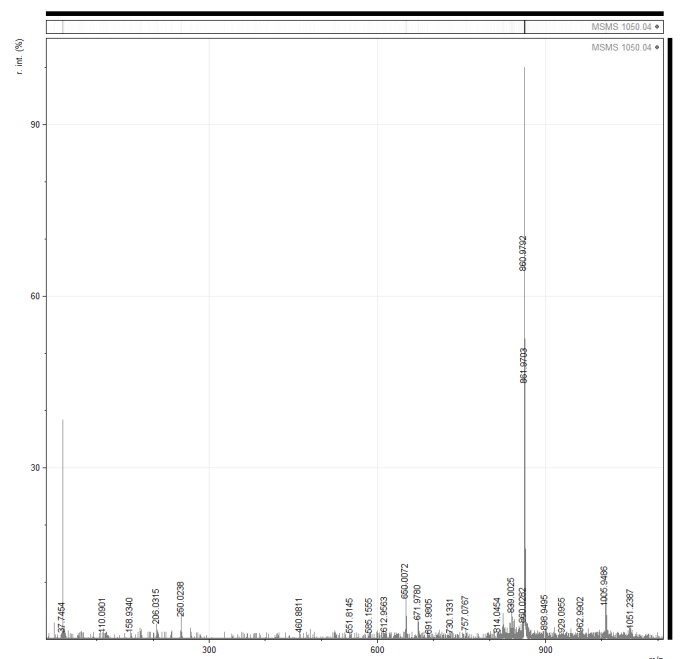

(a)

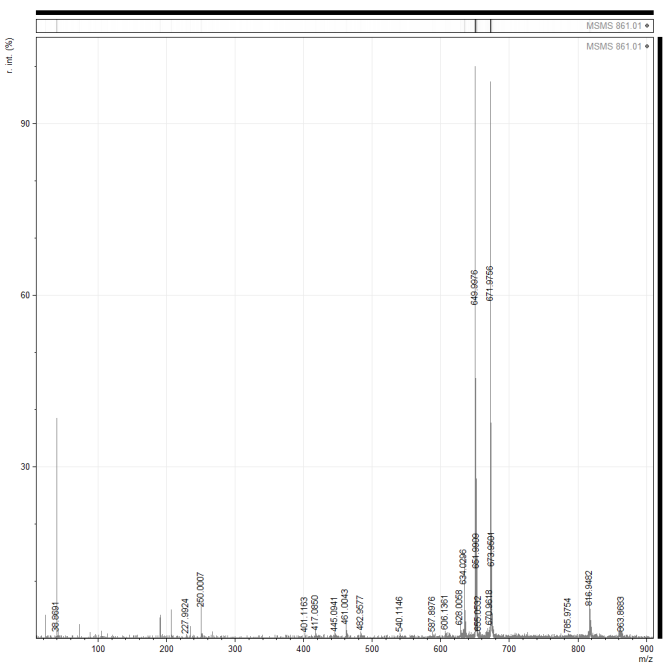

(b)

Figure 3. Matrix-assisted laser desorption/ionization time-of-flight/time-of-flight (MALDI-TOF/TOF) analysis of two signals from fraction Zs G50-III mass spectrum. The figure shows the relative intensity (r.int) versus mass-to-charge ratio $(m / z)$. (a) MALDI-TOF/TOF analysis of $m / z 1050.04$, where the most intense signal corresponds to $m / z$ 860.97; and (b) MALDI-TOF/TOF analysis of $m / z$ 861.01.

In addition, the signal of $m / z 1050.04$ matched a reported microcystin, MC- $\left(\mathrm{H}_{4}\right)$ YR [31,32]. Within the most intense signals $\mathrm{m} / z 860.97$ and $\mathrm{m} / z 861.97$ were found, resembling isotopic peaks (Figure 3). Similarly, in the MALDI-TOF analysis of fraction Zs G50-III, the $m / z 861.01$ was detected as one of the most intense signals. In addition, the fragmentation pattern of $m / z 1050.04$ and $\mathrm{m} / z 861.01$ showed some common signals (Figure 3). Contrasting with the analysis of $m / z 1066.00$, it was not possible to match the fragments of $m / z 1050$ with known signals from the fragmentation of MC- $\left(\mathrm{H}_{4}\right)$ YR [31]. The diagnostic fragments annotation was hindered because of the limited information from the MC- $\left(\mathrm{H}_{4}\right)$ YR $m / z 1050$ spectrum. Moreover, in this case, the spectrum also lacked the microcystins diagnostic signals like Adda fragments $m / z 135$ and $m / z 163$ [30]. 
Moreover, some microcystin-related $m / z$ signals were detected in the MALDI-TOF analysis of Zs G50-III within the $m / z$ range 960-1050 (Figure 4). These signal are $m / z 960.0830$, microcystin YA (MC-YA) [33]; $m / z$ 981.0593, demethylated variant of MC-LR ([DMAdda5]microcystin-LR) [32]; $m / z$ 995.0931, MC-LR (microcystin-LR) [34]; $m / z$ 1002.1186, [D-Asp3.Ser7]microcystin-E(OMe)E(OMe) [35] or microcystin LY (MC-LY) [36]; $m / z$ 1010.0557, [D-Asp3.Dha7]microcystin-RR [37]; $m / z$ 1024.0260, [D-Asp3]microcystin-RR [38]; $m / z$ 1029.1227, microcystin FR (MC-FR) [39]; $m / z$ 1039.0340, [D-Ser1. ADMAdda5]microcystin-LR [40]; $m / z$ 1045.0357, microcystin YR (MC-YR) [34] or [Dha7]microcystin-HtyR [41]. However, these $m / z$ signals were not successfully sequenced by MS/MS and, subsequently, analytical steps were conducted to corroborate the presence of microcystins.

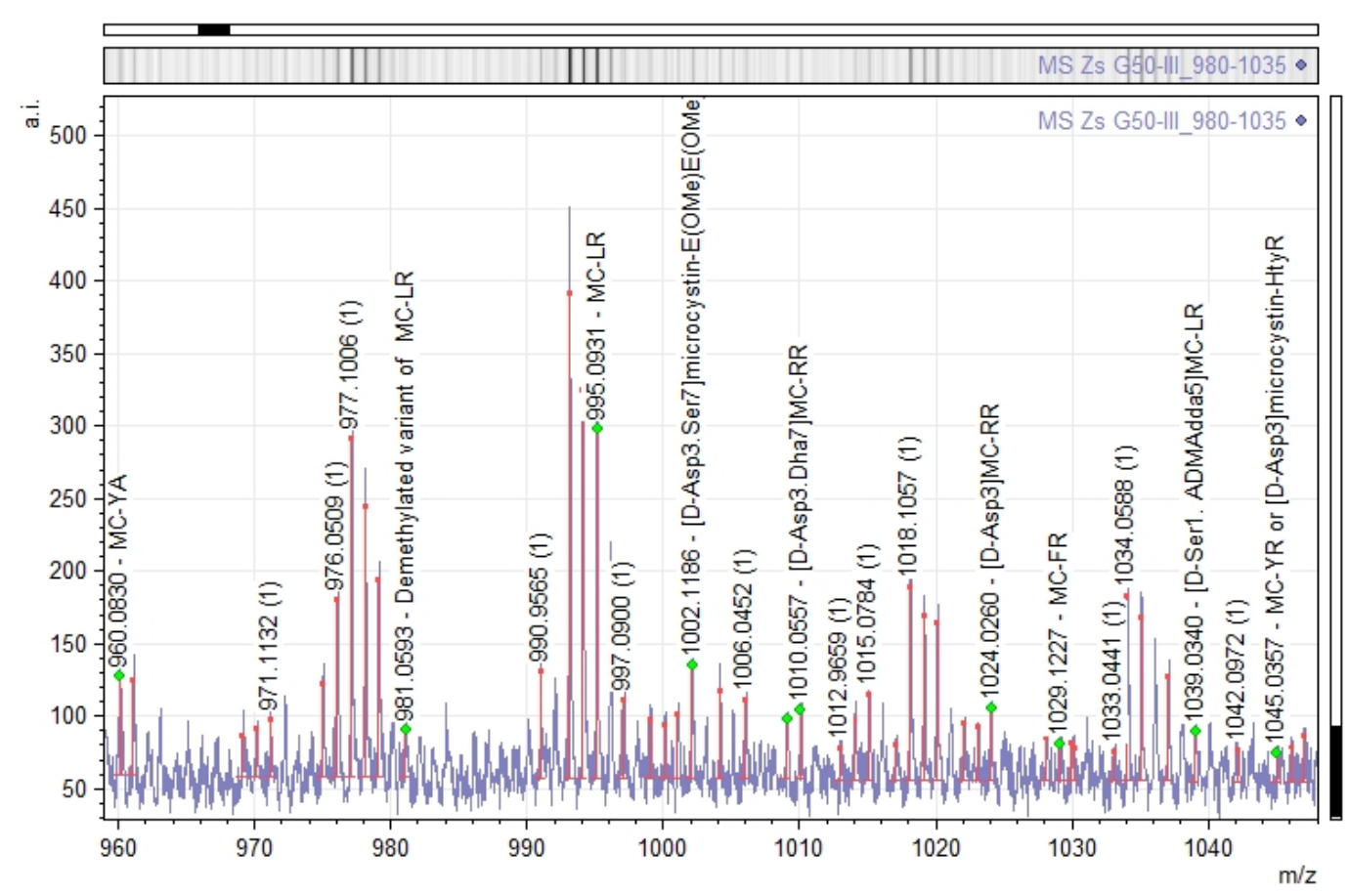

Figure 4. The figure shows absolute intensity (a.i) versus mass-to-charge ratio $(m / z)$ in the $m / z$ range 960-1050 from the MS analysis of fraction Zs G50-III. Some masses are highlighted as annotations, considering similar $m / z$ matches as possible microcystins.

\subsection{Zs G50-III Reserved-Phase Chromatographic Analysis}

\subsubsection{RP-HPLC Analytical Profile}

The detection of some microcystin-related $m / z$ signals, prompted the performance of an analytical chromatographic step to ensure the identification of microcystins. Taking into account that the signal $m / z$ 995.09 matched MC-LR, as the most commonly known and widely distributed microcystins, efforts were focused on confirming the presence of MC-LR in the sample. Therefore, the fraction Zs G50-III was first analysed by RP-HPLC in analytical mode to obtain preliminary information on the sample complexity. The analytical chromatogram showed what we considered as nine peaks of moderate intensity, where the highest relative absorbance was produced by the less retained compounds (Figure 5). Additionally, some of the peaks detected in the analytical chromatogram of the fraction Zs G50-III produced UV spectra with a $\lambda$ max at 220 and $274 \mathrm{~nm}$, while the other peaks' UV maximum-absorbance were around 233, 260, and $300 \mathrm{~nm}$ (Supplementary Figure S1), close to the maximum absorbance of microcystins.

In addition, a chromatogram was obtained with a commercial standard of MC-LR in analytical mode in the same conditions as mentioned for fraction Zs G50-III (Figure 5). The elution time for the MC-LR standard was $8.8 \mathrm{~min}$, whereas in the analytical mode three closely-eluting peaks at 7.3, 
8.0, and 8.6 min were detected. Unlike MC-LR, such peaks do not show maximum absorbance at $238 \mathrm{~nm}$ (Supplementary Figure S1). This behaviour could be explained by insufficient separation of the components.

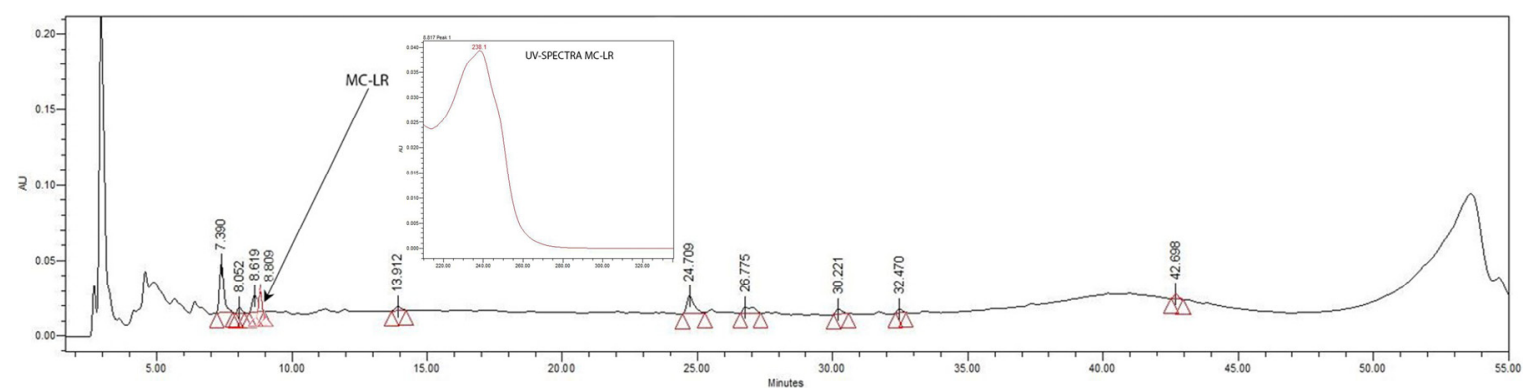

Figure 5. Analytical profile of fraction Zs G50-III, obtained by RP-HPLC. Gradient elution started from $1 \%$ to $99 \% \mathrm{MeOH}$ over $55 \mathrm{~min}$. The injected volume was $10 \mu \mathrm{L}$ at a concentration of $1 \mathrm{mg} / \mathrm{mL}$. The PDA range was $210-400 \mathrm{~nm}$, with fixed wavelengths at $220 \mathrm{~nm}$ and $280 \mathrm{~nm}$. The peak of the commercial standard of MC-LR (in red line) eluted at a retention time of $8.8 \mathrm{~min}$. The injected volume was $10 \mu \mathrm{L}$ at a concentration of $1 \mathrm{mg} / \mathrm{mL}$. The UV spectrum of MC-LR shows maximum absorbance at $238 \mathrm{~nm}$, typical of microcystins.

\subsubsection{Zs G50-III RP-HPLC Semi-Preparative Assays}

Afterwards, a semi-preparative RP-HPLC run (Figure 6) was carried out to separate those components with retention time like that of the commercial MC-LR chromatogram (Figure 5). Unlike microcystins, the UV maximum absorbance for the first peak was $264 \mathrm{~nm}$, whereas the second peak showed a UV maximum absorbance at 220-274 $\mathrm{nm}$ (Supplementary Figure S2), resembling a typical UV spectra of peptides [42-45]. In contrast to Liquid chromatography combining multi-stage mass spectrometry (MC-LC/MS), UV-based methods do not provide unequivocal identification of known, unexpected and/or trace levels of microcystins [46].

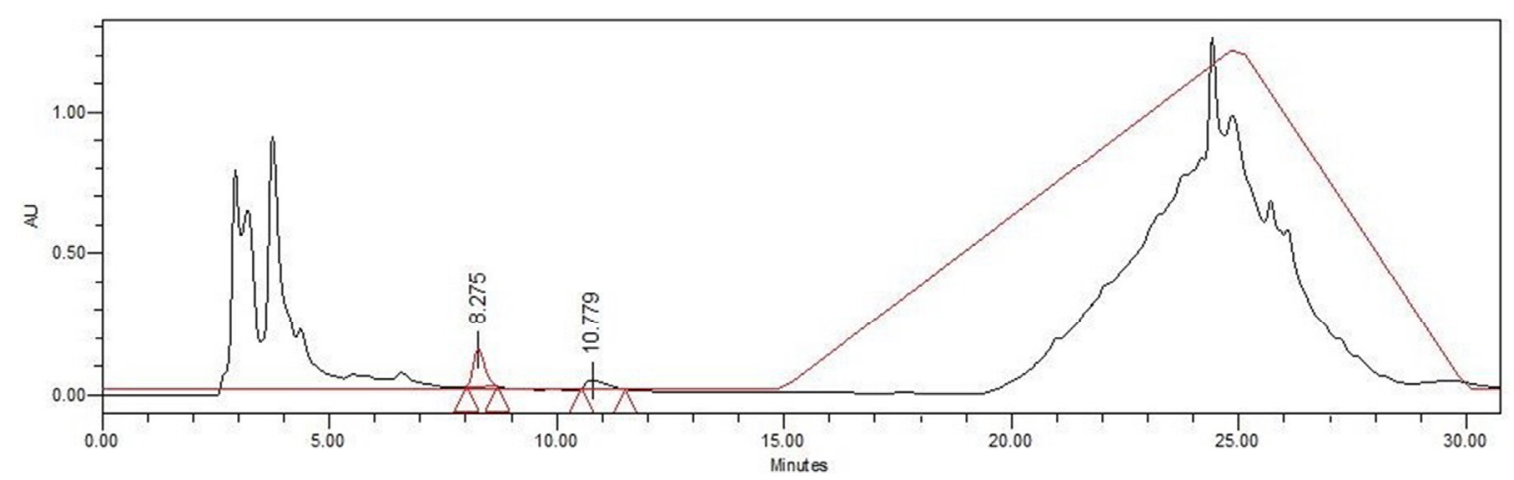

Figure 6. Chromatogram of fraction Zs G50-III subjected to reversed-phase C18 HPLC in isocratic mode with $10 \% \mathrm{MeOH}$ using a $0.1 \% \mathrm{TFA} / \mathrm{H}_{2} \mathrm{O} / \mathrm{MeOH}$ elution system. After $15 \mathrm{~min}$ the solvent was increased from $10 \%$ to $99 \% \mathrm{MeOH}$ over $30 \mathrm{~min}$. The chromatogram obtained by the RP-HPLC procedure shows relative absorbance at $220-280 \mathrm{~nm}$ of two peaks and their respective retention times of $8.2 \mathrm{~min}$ for peak 1 and $10.7 \mathrm{~min}$ for peak 2 .

Nonetheless, the UV spectra of the peaks were not clearly related to MC-LR. Other cyclopeptides with similar elution time, maximum UV absorbance at 220-274 $\mathrm{nm}$ and $m / z$ 995 were previously reported as cyanopeptolin [47]. However, the isomerization [48] and co-elution with another congeners, like cyanopeptolin [47,49] and microginin [50], can produce unusual UV spectra. The co-occurrence of cyanotoxins with other congeners is a common fact supporting the possibility of components 
co-elution. It is noteworthy the presence of putative co-eluting components detected by MS of the peak 2 (Supplementary Figure S3). Unfortunately, the amount of the fraction was limited, and further purification steps based on the gradient elution with phosphoric acid as the mobile phase was not possible to perform as previously reported [50].

\subsection{Identification of MC-LR by MALDI-TOF/TOF Analysis}

The two peaks obtained by RP-HPLC were first submitted to MALDI-TOF MS scan resulting in the detection of $m / z$ values common to both peaks, such as $m / z 795.3,912.3,926.4,930.3 ; 944.4$; 995.5, 1007.4, 1011.5, and 1029.5 (Figure 7). Nonetheless, some differences were detected in the peak list and signal intensity, among which the $m / z 765.33$ showed the highest intensity in peak 1 , whereas 995.53 was the most intense $m / z$ signal in peak 2 . The mentioned $m / z 995.53$ was successfully sequenced via MS/MS analysis of peak 2 (Figure 8) and the resulting spectrum matched the $m / z$ values of some fragments produced by MS/MS analysis of MC-LR (Figure 8). Some fragments from the MS/MS of $m / z 995.53$ were successfully annotated, including $m / z 135$, as a diagnostic characteristic of microcystins. Some of the fragments detected were annotated, such as $m / z 70.07$ [Arg-related ion], m/z 135.09 [Adda fragment], m/z 375.15 [Adda-fragment + Glu + H], 599.27 [Arg + Adda + Glu + H], and 861.33 [M-134]. Others $m / z$ signals, like 1224.59, 1471.68, 1731.82, and 1866.87, corresponding to co-eluting components to the MC-LR $(\mathrm{m} / \mathrm{z}$ 995.53), were also successfully fragmented on peak 2 , (Supplementary Figure S3). Although, it was not possible to identify them, the $m / z$ signal 1731.82 and 1866.87 resembled microviridins previously described [51].

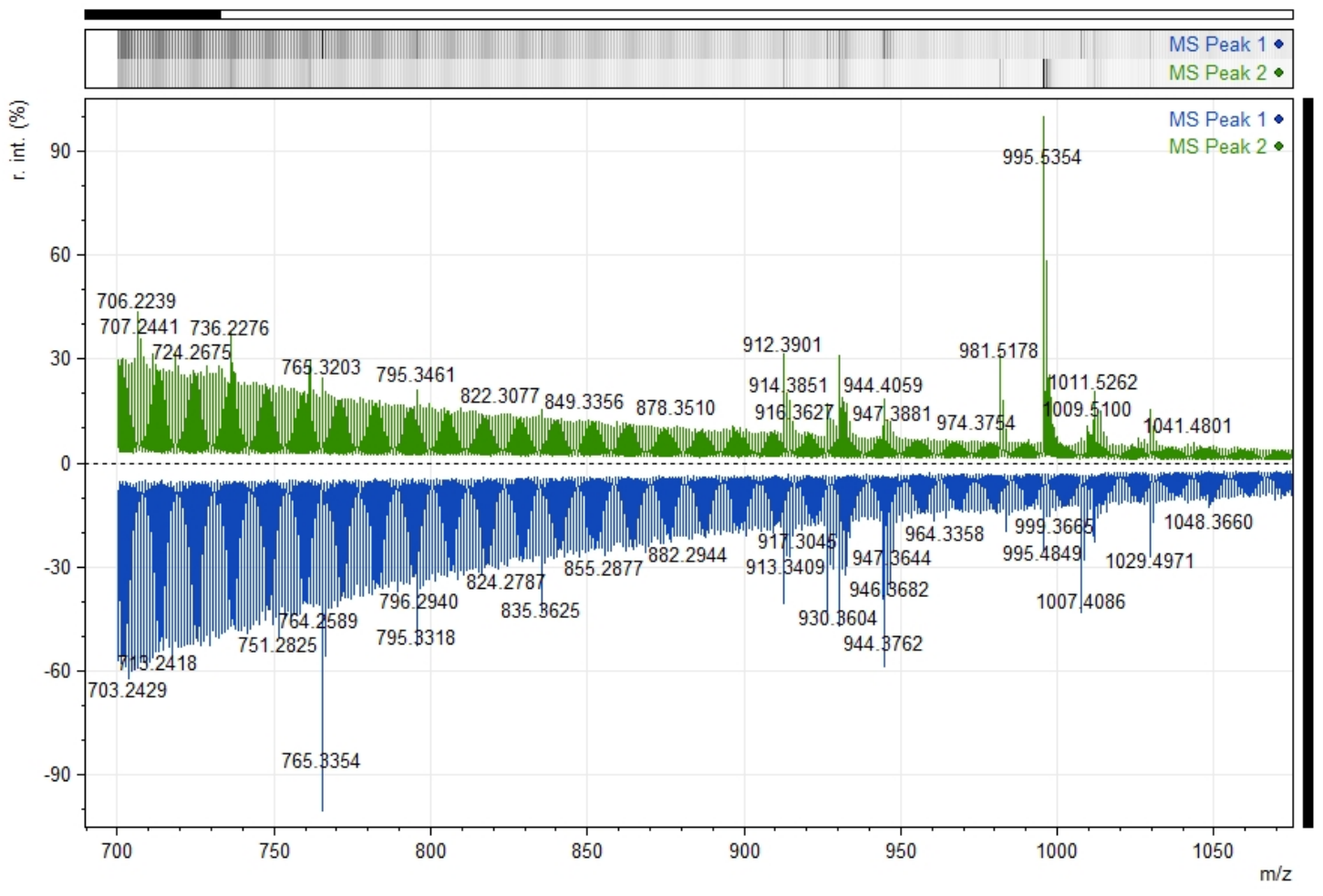

Figure 7. Matrix-assisted laser desorption/ionization time-of-flight/time-of-flight (MALDI-TOF/TOF) mass spectrum of the two RP-HPLC peaks. The composite figure shows relative intensity (r.int) versus mass-to-charge ratio $(\mathrm{m} / \mathrm{z}$ ) in the range of $\mathrm{m} / \mathrm{z} 700-1075$ of peak 1 (blue) peak 2 (green). 


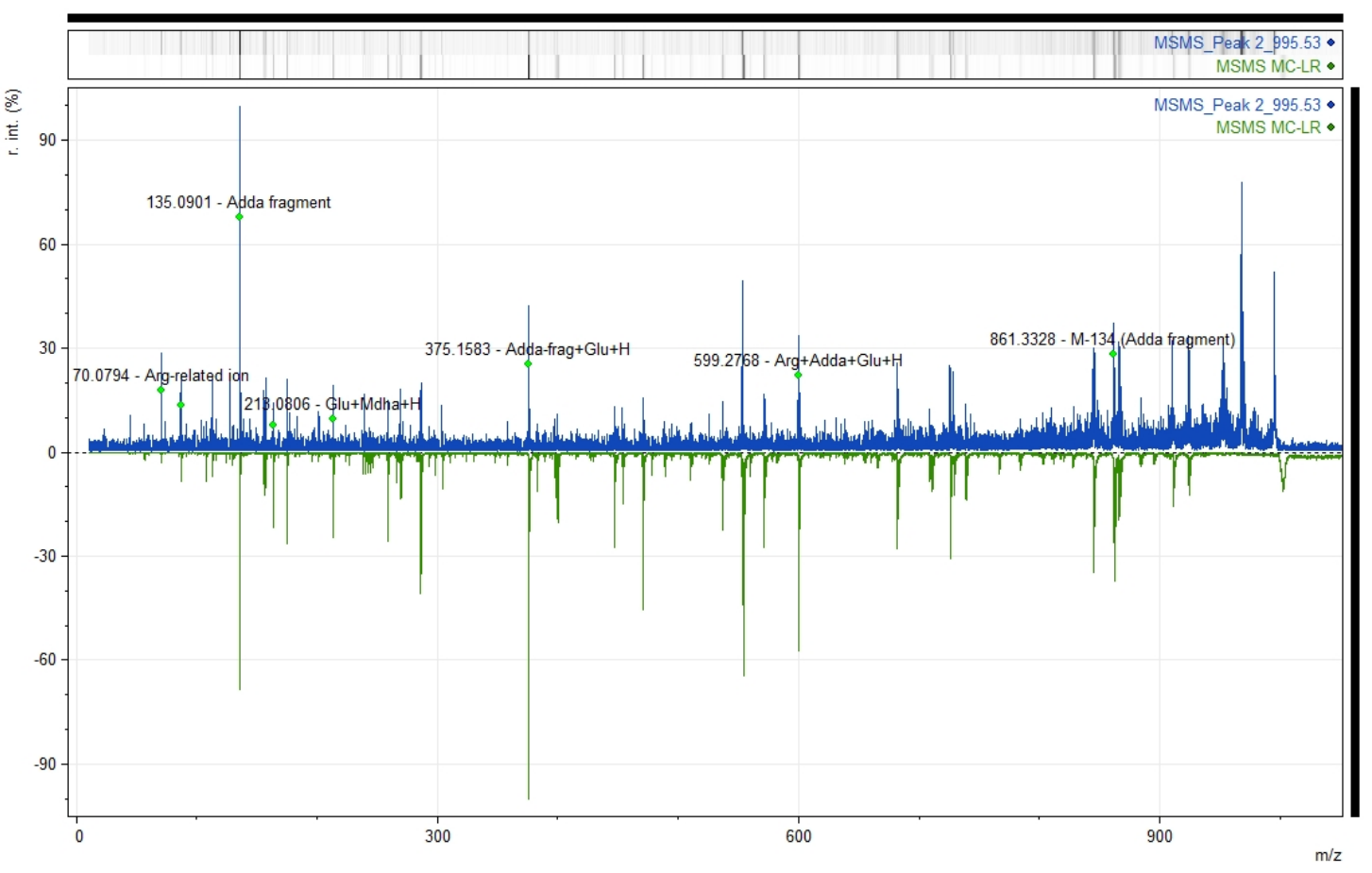

Figure 8. The figure shows relative intensity (r.int) versus mass-to-charge ratio $(\mathrm{m} / \mathrm{z})$ or the spectrum generated by MALDI-TOF/TOF of the signal $\mathrm{m} / \mathrm{z} 995.53$ from peak 2 (color blue, top panel) and the MS/MS of $1 \mu \mathrm{g}$ of an MC-LR commercial standard (blue, bottom panel). Note similarities in the fragmentation pattern in both spectra; the most relevant ions in the identification of the MC-LR are annotated in the top panel.

\subsection{Putative Origins of Microcystins in the Zs G50-III Fraction}

Cyanobacteria also known as blue-green algae are a widely distributed group of photosynthetic prokaryotic organisms [32,52,53]. Some genera like Microcystis, Planktothrix, Anabaena, Nostoc, and Nodularia can produce diverse toxins called cyanotoxins [32]. Within them, the microcystins mostly produced by Microcystis aeruginosa, comprise more than 100 variants of such cyanotoxin [54]. The microcystins are synthesized via a non-ribosomal pathway, where peptide synthetases (NRPS) and polyketide synthases (PKS) play an important role [55]. The general structural of these cyclic heptapeptides are: cyclo [D-Ala(1)-L-X(2)-DMeAsp(3)-L-Z(4)-Adda(5)-D-Glu(6)-Mdha(7)], where $\mathrm{L}-\mathrm{X}$ and $\mathrm{L}-\mathrm{Z}$ in position 2 and 4 of the ring are variable L-amino acids, D-MeAsp is a non-proteogenic aminoacid D-erythro-b-methylaspartic acid, Mdha is N-methyldehydroalanine [56]. The Adda, that is (2S,3S,8S,9S)-3-amino-9-methoxy-2,6,8-trimethyl-10-phenyldeca-4,6-dienoic acid, is a diagnostic characteristic of microcystins. Each microcystin is named depending on the identity of $\mathrm{X}$ and $\mathrm{Z}$ amino acids [30].

Cyanobacteria toxins are more common in world-wide freshwater ecosystems [57,58], although cyanobacteria are widespread in estuarine and marine systems, as well $[59,60]$. However, there are reports on the occurrence of microcystins in marine ecosystems producing hepatic necrosis, haemorrhage, and sudden death in marine mammals [23,61]. The most significant report produced by microcystins intoxication produced the death of 21 southern sea otters [23]. The land-sea flow with trophic transfer through the marine invertebrate-producing bioaccumulation process was demonstrated. It is noteworthy that our specimens belong to the invertebrate Z. sociatus, sampled at the Quibú river mouth, in Havana City. Moreover, this river passes through the city and is likely to be eutrophyzed, providing the proper conditions for the occurrence of microcystins.

Additionally, the confirmation of microcystin-contaminated freshwater outflows to the ocean is not an isolated and sporadic event [23-27]. There is also evidence of microcystins in some marine 
animals, like copepods, corals, and fish $[28,62,63]$. In addition, bioaccumulation of microcystins have been detected on fresh and saltwater mussels [64,65], farmed crustaceans [66,67], fishes [63], and probably in humans [68]. In our case, the cyanobacteria-producing toxins should come from the river flow to the marine zone, occurring as a guest of $Z$. sociatus until being fed. Then microcystins can be incorporated into the $Z$. sociatus tissues. Therefore, we suggest that the most probable source of the toxins detected in our sample is an external producer and not a product of the zoanthid Z. sociatus. However, the hypothesis of $Z$. sociatus as responsible for the production of microcyistin should not be completely discharged, since an analogue of microcystins, called motuporin (analogue of Nodularin-R), was first isolated and described in the marine sponge Theonella swinhoei [69].

Taking into account the high toxicity of microcystins on mammals, specifically in mice [70], the presence of microcystins in the studied fraction could be related to the lethal effects on mice previously reported of a LMW fraction from $Z$. sociatus [19]. In fact, MC-LR and its congeners are highly toxic in mice (lethal dose: $\mathrm{LD}_{50}=50 \mu \mathrm{g} / \mathrm{kg}$ ) when administered intraperitoneally [71]. Unlike Zs G50-III, mostly of the known MC-LR toxic effects are hepatotoxic. In addition, the mentioned studies lack of enough elements to know if MC-LR was tested in an acute toxicity assay producing death in a short time. Nonetheless, the possibilities of MC-LR be involved in cardiotoxic effects could not be discharged, since it is capable of modulating $\mathrm{Ca}^{2+}$ channels. Indeed, the presence of microcystins on the fraction Zs G50-III could also be related to the effects on insulin secretion mediated by $\mathrm{Ca}^{2+}$ influx blockade in isolated rat $\beta$ cells [18]. In fact, exposure to MC-LR for $72 \mathrm{~h}$ suppresses cell viability, disturbs glucose-stimulated insulin secretion, and decreases the expression of insulin protein [72]. Although it is not clear if the presence of microcystins are responsible for the mentioned effects, they are probably largely involved.

\section{Conclusions}

The present work represents one of the few attempts to identify new peptide toxins from the zoanthid Z. sociatus. However, the mass spectrometry analysis of a fraction from Z. sociatus resulted in the detection of masses below $2000 \mathrm{Da}$, among which none sea anemones-like toxins were detected with the Protein Pilot protein identification software and Mascot algorithm search. Nonetheless, some related microcystins masses were detected within the most intense signals generated by the mass spectrometry analysis. One of them, $m / z 995.53$ resulted in a highly similar fragmentation pattern than that of MC-LR standard. Most of the fragment produced by the ionization of the $\mathrm{m} / z 995.53$ were successfully annotated, including $m / z 135.09$ [Adda fragment], as a diagnostic characteristic of microcystins. The combination of the evidences detected led to confirm the presence of MC-LR in the fraction Zs G50-III. To date, this finding constitutes one of the few pieces of evidence of such cyanotoxin being detected in cnidarians, and the first report in the zoanthid Z. sociatus. In the cases of $m / z 1066.00$ and 1050.04, we considered that the information provided by the MS/MS spectra is insufficient to identify these signals as coming from microcystin [9-acetyl-Adda5]-MC-RR and MC- $\left(\mathrm{H}_{4}\right)$ YR, respectively. Additionally, the presence of microcystins in fishing areas with similar conditions to that of the Z. sociatus sampling area remain unexplored in Cuba. Considering the mentioned evidence, the occurrence of microcystins in fishes should be of high probability around the sampling place. Therefore, these findings clearly suggest the underestimated risk of intoxication by microcystins occurring in water and food in a tropical region.

\section{Materials and Methods}

\subsection{Preparation of Crude Extract and Gel Filtration on Sephadex G-50}

The preparation of the Z $Z$. sociatus crude extract was performed from wild-caught colonies sampled at Quibú River mouth, in Havana, Cuba. The gel filtration chromatographic separation on Sephadex G-50 were performed as previously described [19]. Briefly, Z. sociatus specimens were blended after removing their stolonal bases. The whole-body homogenate was filtered through a spun glass mesh, 
and the filtrate was centrifuged twice in a Beckmann CS-6RK centrifuge at $1376 \times g$ for 30 min at $4{ }^{\circ} \mathrm{C}$. The supernatant was freeze-dried overnight and then submitted to fractionation on a Sephadex G-50. The most prominent fraction of the chromatogram, called Zs G50-III was freeze-dried and stored for subsequent experiments.

\subsection{Mass Spectrometry Analysis and Database Search}

Mass spectrometry analysis was performed by MALDI-TOF/TOF (4800 Plus MALDI-TOF/TOF Analyzer; AB SCIEX, Framingham, MA, USA). Mass spectra were analysed with the Data Explorer software (v3.7, build 126, AB SCIEX, Framingham, MA, USA). The samples obtained in the semi-preparative HPLC-PDA separation, corresponding to peaks 2, 3, 4, 5, and 6, were co-crystallized at room temperature with the matrix $\alpha$-cyano-4-hydroxycinnamic acid, $\alpha$-CHCA at $10 \mathrm{mg} / \mathrm{mL}(50 \%$ acetonitrile, and $0.1 \%$ trifluoroacetic acid (TFA)) in a MALDI target plate. Samples were previously concentrated and cleaned according to the manufacturer's instructions on a micro C18 column (ZipTip, Millipore, Bedford, MA, USA). The mass spectra were acquired in positive ion reflector mode from $m / z$ 700 to 4000 . Afterwards, some of these peptides peaks were selected for MS/MS peptide sequencing.

The masses $[\mathrm{M}+\mathrm{H}]^{+}$and the corresponding native intensity of HPLC-PDA peaks obtained from MS scan were exported to ASCII format for further analysis with the mMass 5.5.0 software [73,74]. Firstly, Peak Lists was achieved using the following criteria: peak's signal-to-noise ratio threshold (S/N) 2.0; absolute intensity threshold (a.i) 10.0 (peak's native intensity without baseline correction); relative intensity threshold (r.int.) 0.3 (peak's relative intensity, in percentage of the most intense peak); and picking height of 75. Additionally, baseline correction, smoothing, and deisotoping tools were also applied to all MS fixed at default settings. The matrix $\alpha-\mathrm{CHCA}$ monoisotopic masses $[\mathrm{M}+\mathrm{H}]^{+}$ acquired in the same MS mass window were used as control for calibration. The resulting peak lists were compared to each other using a tolerance of $0.1 \mathrm{Da}$ and different masses were determined. Finally, all different candidates' masses $[\mathrm{M}+\mathrm{H}]^{+}$were corroborated in each MS (each MS-peak-spectrum against MS-matrix-spectrum) in both mode Autoscale and Normalize View.

The data generated by MALDI-TOF/TOF procedure were submitted to search with the Mascot (Matrix-Science, London, UK) algorithm. The protein identification was carried out from UniProtKB protein sequence database [29] in the Metazoa and Cnidaria section. The Mascot search parameters were fixed as follows: up to two maximum trypsin missed cleavages, mass tolerance of 50 ppm, cysteine carbamidomethylation (fixed modification), methionine oxidation (variable modification), and a charge state of +1 . The same data mentioned were also analysed by Protein Pilot protein identification software v4.5 (AB SCIEX). The protein identification was carried out from UniProtKB protein sequence database in the Metazoa and Cnidaria section. Only those proteins matched with scores at a $95 \%$ confidence level were considered as significant hits.

Moreover, all spectra generated for each peak were also analyzed by a mass-matching tool provided by the mMass software v5.5.0 [73,74]. In this case, the analysis was carried out within the internal monomer mMass library and also against the imported non-ribosomal peptides library (NORINE peptide database, available in the mMass homepage at the download section http://www. mmass.org/download/), adapted from the original NORINE database [21]. The matched masses were then examined, and their spectra were analyzed. The fragmentation pattern was compared to a standard or available reference, in the case of those that were of interest.

\section{MALDI-TOF/TOF Raw Data Availability}

The output files generated by MALDI-TOF/TOF analyses used in this work are provided in ASCII format as Supplementary Raw Dataset S1. Within the package are included the following folders containing the respective mass spectra (MS/MS): Matrix (MALDI TOF/TOF MS of matrix used as control; MS_Zs G50-III (MS of studied fraction Zs G50-III); MS/MS_1066_\&_876 (MS/MS of the signals $m / z 1066.00$ and 876.94 from the MS of fraction Zs G50-III); MS/MS_1050_\&_861 (MS/MS of the signals $m / z 1050.04$ and 861.01 from the MS of fraction Zs G50-III); Peak 1 (MS of Peak 1 was obtained 
by RP-PHLC from Zs G50-III fraction); Peak 2 (MS of Peak 2 was obtained by RP-PHLC from the Zs G50-III fraction, and the MS/MS of the signals $m / z$ 995.53, 1224.59, 1471.68, 1731.82, and 18,866.87), and MS_\&_MS/MS_MC-LR (MS of the commercial standard of MC-LR, and MS/MS of the signals $m / z 995.53$ and 981.50 were obtained from the MS of MC-LR).

\subsection{Reserved-Phase Chromatographic Analysis}

All solvents used in RP-HPLC analyses were of high-purity chromatography grade (LiChrosolv, Merck, Darmstadt, Germany). Aqueous solutions were prepared with ultrapure water supplied from a Millipore water purification system $\left(0.0054 \mu \mathrm{S} \cdot \mathrm{cm}^{-1}\right)$. Trifluoroacetic acid (TFA) was of spectrophotometric grade 99\%. The chromatographic system used for RP-HPLC separations was a Waters Alliance e2695 HPLC coupled with a photodiode array (PDA) 2998 and an automatic fraction collector. Empower Two Chromatography Data Software was used for calculation and reporting peak information. All HPLC solvents were filtered (Pall GH Polypro $47 \mathrm{~mm}, 0.2 \mu \mathrm{m}$ ) and degassed by an ultrasonic bath.

The analytical profile was obtained on a Merck Lichrospher RP-18 endcapped reversed-phase column $(250 \mathrm{~mm} \times 4.6 \mathrm{~mm}$ i.d., $5 \mu \mathrm{m})$ equipped with a guard column $(4 \times 4 \mathrm{~mm}, 5 \mu \mathrm{m})$, both kept at $40{ }^{\circ} \mathrm{C}$. The PDA wavelength range was $210-800 \mathrm{~nm}$ with fixed values at 220 and $280 \mathrm{~nm}$. The solvent system consisted of MilliQ water $\left(\mathrm{H}_{2} \mathrm{O}\right)$ and methanol $(\mathrm{MeOH})$, both acidified with $0.1 \%$ TFA. A linear gradient from $1 \%$ to $99 \% \mathrm{MeOH}$ was applied in the analytical run to explore the complexity of the sample and the elution time of the commercial standard of Microcystin-LR (DHI Water and Environment, Denmark; Batch No: MCLR-111).

The purification step was performed using a Phenomenex Luna RP-18 $(25 \mathrm{~cm} \times 10 \mathrm{~mm}, 10 \mu \mathrm{m})$ chromatographic column kept at $35{ }^{\circ} \mathrm{C}$. The PDA range was $210-800 \mathrm{~nm}$ with fixed wavelengths of 220 and $280 \mathrm{~nm}$. For the isocratic elution, $0.1 \%$ TFA in 10\% MeOH was used as eluent at a flow rate of $2.5 \mathrm{~mL} / \mathrm{min}$. Eventually, the solvent of the mobile phase was increased to $50 \% \mathrm{MeOH}$. The concentration of total-proteins estimated was $1 \mathrm{mg} / \mathrm{mL}$, and injected in a final volume of $200 \mu \mathrm{L}$. The fractions were automatically collected following the PDA signal. The fractions of interest were dried up by speed vac and kept at $-20^{\circ} \mathrm{C}$ for subsequent analysis.

Supplementary Materials: The following are available online at www.mdpi.com/2072-6651/9/3/89/s1, Figure S1: The figure shows the UV spectra of peaks obtained from the RP-HPLC analytical profile of fraction ZsG50-III, Figure S2: The figure shows the UV spectra of two peaks obtained from the RP-HPLC of the fraction ZsG50-III in a semi-preparative mode, Figure S3: Matrix assisted laser desorption/ionization time-of-flight/time-of-flight(MALDI-TOF/TOF) mass spectra (MS) of the RP-HPLC Peak 2 and Supplementary Raw Dataset S1.

Acknowledgments: Dany Domínguez Pérez was supported by a Ph.D. grant (SFRH/BD/80592/2011) from the Portuguese Foundation for Science and Technology (FCT-Fundação para a Ciência e a Tecnologia, Portugal). Armando A Rodríguez was supported by an Alexander von Humboldt postdoctoral fellowship (3.2-KUB/1153731 STP). We are grateful to Carlos Manlio Diaz-García (from Department of Neurobiology, Harvard Medical School, Boston, MA, USA) for his useful comments and to Carlos Varela (Department of Biological Sciences, Florida International University (FIU), FL, USA) for providing Z. sociatus specimens. This study was funded in part by the Strategic Funding UID/Multi/04423/2013 through national funds provided by FCT and the European Regional Development Fund (ERDF) in the framework of the program PT2020, by the European Structural and Investment Funds (ESIF) through the Competitiveness and Internationalization Operational Program-COMPETE 2020 and by National Funds through the FCT under the project PTDC/AAG-GLO/6887/2014 (POCI-01-0124-FEDER-016845), and by the Structured Programs of R\&D\&I INNOVMAR-Innovation and Sustainability in the Management and Exploitation of Marine Resources (NORTE-01-0145-FEDER-000035, Research Line NOVELMAR) and MarInfo-Integrated Platform for Marine Data Acquisition and Analysis (NORTE-01-0145-FEDER-000031), and funded by the Northern Regional Operational Program (NORTE2020) through the ERDF.

Author Contributions: Conceived and designed the experiments: D.D.-P., V.V., O.C., A.A. Supervised and contributed reagents/materials: V.V., O.C., A.A. Crude extract preparation: D.D.-P. Sephadex G-50 gel filtration: D.D.-P., A.A.-R. HPLC analysis: J.A. MALDI-TOF/TOF analysis: H.O. Analyzed, discussed and performed the figures: D.D.-P., J.A., H.O., A.A.-R. Wrote the paper: D.D.-P., A.A.-R., A.A.

Conflicts of Interest: The authors declare no conflict of interest. 


\section{Abbreviations}

The following abbreviations are used in this manuscript:

$\begin{array}{ll}\text { LMW } & \text { Low molecular weight } \\ \text { MALDI-TOF/TOF } & \text { Matrix assisted laser desorption/ionization time-of-fly/time-of-fly } \\ \text { MS } & \text { Mass spectra } \\ m / z & \text { Mass-to-charge ratio } \\ \text { a.i } & \text { Absolute intensity } \\ \text { int } & \text { Peak's corrected intensity } \\ \text { r.int } & \text { Relative intensity } \\ \text { S/N } & \text { Peak's signal-to-noise ratio } \\ \text { mass } & \text { Neutral mass } \\ \text { fwhm } & \text { Full width at half maximum } \\ \text { resol } & \text { resolution } \\ \text { NORINE } & \text { Non-ribosomal peptide database } \\ \text { HPLC } & \text { High Performance Liquid Chromatographic } \\ \text { RP } & \text { Reverse Phase } \\ \text { MC-LR } & \text { Microcystin LR } \\ \text { Z. sociatus } & \text { Zoanthus sociatus } \\ \text { TTX } & \text { tetrodotoxin } \\ \text { Palythoa caribaeorum } & \text { P. caribaeourum } \\ \text { LC/ESI-Q-ToF } & \text { Liquid Chromatography/Electrospray ionization coupled to } \\ \text { Adda } & \text { Quadruple Time-of-flight } \\ \text { LD } & \text { 3-amino-9-methoxy-2,6,8-trimethyl-10-phenyl-deca-4,6-dienoic acid } \\ \text { UV } & \text { Lethal Dose } \\ \text { TFA } & \text { Ultraviolet } \\ \text { PDA } & \text { Trifluoroacetic acid } \\ & \text { Photodiode Array }\end{array}$

\section{References}

1. Yan, L.; Herrington, J.; Goldberg, E.; Dulski, P.M.; Bugianesi, R.M.; Slaughter, R.S.; Banerjee, P.; Brochu, R.M.; Priest, B.T.; Kaczorowski, G.J.; et al. Stichodactyla helianthus peptide, a pharmacological tool for studying Kv3.2 channels. Mol. Pharmacol. 2005, 67, 1513-1521. [CrossRef] [PubMed]

2. Tejuca, M.; Diaz, I.; Figueredo, R.; Roque, L.; Pazos, F.; Martinez, D.; Iznaga-Escobar, N.; Perez, R.; Alvarez, C.; Lanio, M.E. Construction of an immunotoxin with the pore forming protein StI and ior C5, a monoclonal antibody against a colon cancer cell line. Int. Immunopharmacol. 2004, 4, 731-744. [CrossRef] [PubMed]

3. Beeton, C.; Pennington, M.W.; Wulff, H.; Singh, S.; Nugent, D.; Crossley, G.; Khaytin, I.; Calabresi, P.A.; Chen, C.Y.; Gutman, G.A.; et al. Targeting effector memory T cells with a selective peptide inhibitor of Kv1.3 channels for therapy of autoimmune diseases. Mol. Pharmacol. 2005, 67, 1369-1381. [CrossRef] [PubMed]

4. Chi, V.; Pennington, M.W.; Norton, R.S.; Tarcha, E.J.; Londono, L.M.; Sims-Fahey, B.; Upadhyay, S.K.; Lakey, J.T.; Iadonato, S.; Wulff, H.; et al. Development of a sea anemone toxin as an immunomodulator for therapy of autoimmune diseases. Toxicon 2012, 59, 529-546. [CrossRef] [PubMed]

5. Honma, T.; Shiomi, K. Peptide toxins in sea anemones: Structural and functional aspects. Mar. Biotechnol. 2006, 8, 1-10. [CrossRef] [PubMed]

6. Oliveira, J.S.; Fuentes-Silva, D.; King, G.F. Development of a rational nomenclature for naming peptide and protein toxins from sea anemones. Toxicon 2012, 60, 539-550. [CrossRef] [PubMed]

7. Frazão, B.; Vasconcelos, V.; Antunes, A. Sea anemone (cnidaria, anthozoa, actiniaria) toxins: An overview. Mar. Drugs 2012, 10, 1812-1851. [CrossRef] [PubMed]

8. Norton, R.S. Structures of sea anemone toxins. Toxicon 2009, 54, 1075-1088. [CrossRef] [PubMed]

9. Beress, L. Biologically active compounds from coelenterates. Pure Appl. Chem. 1982, 54, 1981-1994. [CrossRef]

10. Wu, C.H. Palytoxin: Membrane mechanisms of action. Toxicon 2009, 54, 1183-1189. [CrossRef] [PubMed]

11. Deeds, J.R.; Handy, S.M.; White, K.D.; Reimer, J.D. Palytoxin found in Palythoa sp. zoanthids (anthozoa, hexacorallia) sold in the home aquarium trade. PLoS ONE 2011, 6, e18235. [CrossRef] [PubMed] 
12. Lazcano-Perez, F.; Vivas, O.; Roman-Gonzalez, S.A.; Rodriguez-Bustamante, E.; Castro, H.; Arenas, I.; Garcia, D.E.; Sanchez-Puig, N.; Arreguin-Espinosa, R. A purified Palythoa venom fraction delays sodium current inactivation in sympathetic neurons. Toxicon 2014, 82, 112-116. [CrossRef] [PubMed]

13. Chen Huang, J.-E.R.M.; Zhou, H.; Lima, E.P.; Gomes, P.B.; Perez, C.D.; Lou, I.; Lee, S.M.Y.; Radis-Baptista, G. Basal repertoire of toxin-related transcripts in the zoanthid Protopalythoa variabilis (cnidaria, anthozoa). CJPT 2015, 29, 104-105.

14. Kelecom, A. Studies of Brazilian marine invertebrates. VIII. Zoanthosterol, a new sterol from the zoanthid Zoanthus sociatus (hexacorallia, zoanthidea). Bull. Soc. Chim. Belges 1981, 90, 971-976. [CrossRef]

15. Fukuzawa, S.; Hayashi, Y.; Uemura, D. The isolation and structures of five new alkaloids, norzoanthamine, oxyzoanth amine, norzoanthaminone, cyclozoanthamine and epinorzoanthamine. Heterocycl. Commun. 1995, 1, 207-214. [CrossRef]

16. Cen-Pacheco, F.; Martin, M.N.; Fernandez, J.J.; Hernandez Daranas, A. New oxidized zoanthamines from a Canary Islands Zoanthus sp. Mar. Drugs 2014, 12, 5188-5196. [CrossRef] [PubMed]

17. Lakshmi, V.; Saxena, A.; Pandey, K.; Bajpai, P.; Misra-Bhattacharya, S. Antifilarial activity of Zoanthus species (phylum coelenterata, class anthzoa) against human lymphatic filaria, Brugia malayi. Parasitol. Res. 2004, 93, 268-273. [CrossRef] [PubMed]

18. Diaz-Garcia, C.M.; Sanchez-Soto, C.; Fuentes-Silva, D.; Leon-Pinzon, C.; Dominguez-Perez, D.; Varela, C.; Rodriguez-Romero, A.; Castaneda, O.; Hiriart, M. Low molecular weight compounds from Zoanthus sociatus impair insulin secretion via $\mathrm{Ca}^{+2}$ influx blockade and cause glucose intolerance in vivo. Toxicon 2012, 59, 306-314. [CrossRef] [PubMed]

19. Dominguez-Perez, D.; Diaz-Garcia, C.M.; Garcia-Delgado, N.; Sierra-Gomez, Y.; Castaneda, O.; Antunes, A. Insights into the toxicological properties of a low molecular weight fraction from Zoanthus sociatus (cnidaria). Mar. Drugs 2013, 11, 2873-2881. [CrossRef] [PubMed]

20. Perkins, D.N.; Pappin, D.J.; Creasy, D.M.; Cottrell, J.S. Probability-based protein identification by searching sequence databases using mass spectrometry data. Electrophoresis 1999, 20, 3551-3567. [CrossRef]

21. Caboche, S.; Pupin, M.; Leclère, V.; Fontaine, A.; Jacques, P.; Kucherov, G. Norine: A database of nonribosomal peptides. Nucleic Acids Res. 2008, 36, D326-D331. [CrossRef] [PubMed]

22. Caboche, S.; Leclere, V.; Pupin, M.; Kucherov, G.; Jacques, P. Diversity of monomers in nonribosomal peptides: Towards the prediction of origin and biological activity. J. Bacteriol. 2010, 192, 5143-5150. [CrossRef] [PubMed]

23. Miller, M.A.; Kudela, R.M.; Mekebri, A.; Crane, D.; Oates, S.C.; Tinker, M.T.; Staedler, M.; Miller, W.A.; Toy-Choutka, S.; Dominik, C.; et al. Evidence for a novel marine harmful algal bloom: Cyanotoxin (microcystin) transfer from land to sea otters. PLoS ONE 2010, 5, e12576. [CrossRef] [PubMed]

24. Chen, D.Z.X.; Boland, M.P.; Smillie, M.A.; Klix, H.; Ptak, C.; Andersen, R.J.; Holmes, C.F.B. Identification of protein phosphatase inhibitors of the microcystin class in the marine environment. Toxicon 1993, 31, 1407-1414. [CrossRef]

25. Lehman, P.W.; Boyer, G.; Hall, C.; Waller, S.; Gehrts, K. Distribution and toxicity of a new colonial Microcystis aeruginosa bloom in the San Francisco Bay Estuary, California. Hydrobiologia 2005, 541, 87-99. [CrossRef]

26. Matthiensen, A.; Beattie, K.A.; Yunes, J.S.; Kaya, K.; Codd, G.A. [d-leu1]Microcystin-LR, from the cyanobacterium Microcystis RST 9501 and from a Microcystis bloom in the Patos Lagoon estuary, Brazil. Phytochemistry 2000, 55, 383-387. [CrossRef]

27. Tonk, L.; Bosch, K.; Visser, P.M.; Huisman, J. Salt tolerance of the harmful cyanobacterium Microcystis aeruginosa. Aquat. Microb. Ecol. 2007, 46, 117-123. [CrossRef]

28. Richardson, L.L.; Sekar, R.; Myers, J.L.; Gantar, M.; Voss, J.D.; Kaczmarsky, L.; Remily, E.R.; Boyer, G.L.; Zimba, P.V. The presence of the cyanobacterial toxin microcystin in black band disease of corals. FEMS Microbiol. Lett. 2007, 272, 182-187. [CrossRef] [PubMed]

29. Boutet, E.; Lieberherr, D.; Tognolli, M.; Schneider, M.; Bansal, P.; Bridge, A.J.; Poux, S.; Bougueleret, L.; Xenarios, I. Uniprotkb/swiss-prot, the manually annotated section of the uniprot knowledgebase: How to use the entry view. Methods Mol. Biol. (Clifton, N.J.) 2016, 1374, 23-54.

30. Ferranti, P.; Fabbrocino, S.; Nasi, A.; Caira, S.; Bruno, M.; Serpe, L.; Gallo, P. Liquid chromatography coupled to quadruple time-of-flight tandem mass spectrometry for microcystin analysis in freshwaters: Method performances and characterisation of a novel variant of Microcystin-RR. Rapid Commun. Mass Spectrom. 2009, 23, 1328-1336. [CrossRef] [PubMed] 
31. Mbukwa, E.A.; Msagati, T.A.M.; Mamba, B.B. Quantitative variations of intracellular Microcystin-LR, -RR and -YR in samples collected from four locations in Hartbeespoort Dam in North West province (South Africa) during the 2010/2011 summer season. Int. J. Environ. Res. Public Health 2012, 9, 3484-3505. [CrossRef] [PubMed]

32. Namikoshi, M.; Sun, F.; Choi, B.W.; Rinehart, K.L.; Carmichael, W.W.; Evans, W.R.; Beasley, V.R. Seven more microcystins from homer lake cells: Application of the general method for structure assignment of peptides containing. Alpha.,.Beta.-dehydroamino acid unit(s). J. Org. Chem. 1995, 60, 3671-3679. [CrossRef]

33. Vasas, G.; Szydlowska, D.; Gaspar, A.; Welker, M.; Trojanowicz, M.; Borbely, G. Determination of microcystins in environmental samples using capillary electrophoresis. J. Biochem. Biophys. Methods 2006, 66, 87-97. [CrossRef] [PubMed]

34. Bogialli, S.; Bruno, M.; Curini, R.; Di Corcia, A.; Lagana, A.; Mari, B. Simple assay for analyzing five microcystins and nodularin in fish muscle tissue: Hot water extraction followed by liquid chromatography-tandem mass spectrometry. J. Agric. Food Chem. 2005, 53, 6586-6592. [CrossRef] [PubMed]

35. Namikoshi, M.; Yuan, M.; Sivonen, K.; Carmichael, W.W.; Rinehart, K.L.; Rouhiainen, L.; Sun, F.; Brittain, S.; Otsuki, A. Seven new microcystins possessing two L-glutamic acid units, isolated from Anabaena sp. Strain 186. Chem. Res. Toxicol. 1998, 11, 143-149. [CrossRef] [PubMed]

36. Stoner, R.D.; Adams, W.H.; Slatkin, D.N.; Siegelman, H.W. The effects of single L-amino acid substitutions on the lethal potencies of the microcystins. Toxicon 1989, 27, 825-828. [CrossRef]

37. Sivonen, K.; Namikoshi, M.; Evans, W.R.; Carmichael, W.W.; Sun, F.; Rouhiainen, L.; Luukkainen, R.; Rinehart, K.L. Isolation and characterization of a variety of microcystins from seven strains of the cyanobacterial genus Anabaena. Appl. Environ. Microbiol. 1992, 58, 2495-2500. [PubMed]

38. Meriluoto, J.A.; Sandstrom, A.; Eriksson, J.E.; Remaud, G.; Craig, A.G.; Chattopadhyaya, J. Structure and toxicity of a peptide hepatotoxin from the cyanobacterium Oscillatoria agardhii. Toxicon 1989, 27, 1021-1034. [CrossRef]

39. Namikoshi, M.; Rinehart, K.L.; Sakai, R.; Stotts, R.R.; Dahlem, A.M.; Beasley, V.R.; Carmichael, W.W.; Evans, W.R. Identification of 12 hepatotoxins from a homer lake bloom of the cyanobacteria Microcystis aeruginosa, Microcystis viridis, and Microcystis wesenbergii: Nine new microcystins. J. Org. Chem. 1992, 57, 866-872. [CrossRef]

40. Sivonen, K.; Namikoshi, M.; Evans, W.R.; Fardig, M.; Carmichael, W.W.; Rinehart, K.L. Three new microcystins, cyclic heptapeptide hepatotoxins, from Nostoc sp. Strain 152. Chem. Res. Toxicol. 1992, 5, 464-469. [CrossRef] [PubMed]

41. Namikoshi, M.; Sivonen, K.; Evans, W.R.; Carmichael, W.W.; Rouhiainen, L.; Luukkainen, R.; Rinehart, K.L. Structures of three new homotyrosine-containing microcystins and a new homophenylalanine variant from Anabaena sp. Strain 66. Chem. Res. Toxicol. 1992, 5, 661-666. [CrossRef] [PubMed]

42. Liyanage, M.R.; Bakshi, K.; Volkin, D.B.; Middaugh, C.R. Ultraviolet Absorption Spectroscopy of Peptides. In Therapeutic Peptides: Methods and Protocols; Nixon, E.A., Ed.; Humana Press: Totowa, NJ, USA, 2014; pp. 225-236.

43. Scopes, R. Measurement of protein by spectrophotometry at $205 \mathrm{~nm}$. Anal. Biochem. 1974, 59, $277-282$. [CrossRef]

44. Anthis, N.J.; Clore, G.M. Sequence-specific determination of protein and peptide concentrations by absorbance at $205 \mathrm{~nm}$. Protein Sci. Publ. Protein Soc. 2013, 22, 851-858. [CrossRef] [PubMed]

45. Gill, S.C.; von Hippel, P.H. Calculation of protein extinction coefficients from amino acid sequence data. Anal. Biochem. 1989, 182, 319-326. [CrossRef]

46. Zhang, T.; Kiyonami, R.; Wang, L.; Jiang, G. Identification and Quantitation of Microcystins by Targeted Full-Scan LC-MS/MS. In Application Note 569; Thermo-Fisher-Scientific: San Jose, CA, USA, 2016.

47. Neumann, U.; Campos, V.; Cantarero, S.; Urrutia, H.; Heinze, R.; Weckesser, J.; Erhard, M. Co-occurrence of non-toxic (cyanopeptolin) and toxic (microcystin) peptides in a bloom of Microcystis sp. from a Chilean lake. Syst. Appl. Microbiol. 2000, 23, 191-197. [CrossRef]

48. Tsuji, K.; Watanuki, T.; Kondo, F.; Watanabe, M.F.; Suzuki, S.; Nakazawa, H.; Suzuki, M.; Uchida, H.; Harada, K.-I. Stability of microcystins from cyanobacteria-II. Effect of UV light on decomposition and isomerization. Toxicon 1995, 33, 1619-1631. [CrossRef]

49. Martin, C.; Oberer, L.; Ino, T.; Konig, W.A.; Busch, M.; Weckesser, J. Cyanopeptolins, new depsipeptides from the cyanobacterium Microcystis sp. PCC 7806. J. Antibiot. 1993, 46, 1550-1556. [CrossRef] [PubMed] 
50. Carneiro, R.L.; Dörr, F.A.; Dörr, F.; Bortoli, S.; Delherbe, N.; Vásquez, M.; Pinto, E. Co-occurrence of microcystin and microginin congeners in Brazilian strains of Microcystis sp. FEMS Microbiol. Ecol. 2012, 82, 692-702. [CrossRef] [PubMed]

51. Puddick, J.; Prinsep, M.R.; Wood, S.A.; Kaufononga, S.A.F.; Cary, S.C.; Hamilton, D.P. High levels of structural diversity observed in microcystins from Microcystis CAWBG11 and characterization of six new microcystin congeners. Mar. Drugs 2014, 12, 5372-5395. [CrossRef] [PubMed]

52. Taton, A.; Grubisic, S.; Balthasart, P.; Hodgson, D.A.; Laybourn-Parry, J.; Wilmotte, A. Biogeographical distribution and ecological ranges of benthic cyanobacteria in East Antarctic Lakes. FEMS Microbiol. Ecol. 2006, 57, 272-289. [CrossRef] [PubMed]

53. Fumanti, B.; Cavacini, P.; Alfinito, S. Benthic algal mats of some lakes of Inexpressible Island (Northern Victoria Land, Antarctica). Polar Biol. 1997, 17, 25-30. [CrossRef]

54. Timo, N. Microcystin Congeners Described in the Literature. Available online: https://figshare.Com/ articles/_microcystin_congeners_described_in_the_literature/880756 (accessed on 26 January 2017).

55. Tillett, D.; Dittmann, E.; Erhard, M.; von Dohren, H.; Borner, T.; Neilan, B.A. Structural organization of microcystin biosynthesis in Microcystis aeruginosa PCC7806: An integrated peptide-polyketide synthetase system. Chem. Biol. 2000, 7, 753-764. [CrossRef]

56. Carmichael, W.W. Cyanobacteria secondary metabolites-the cyanotoxins. J. Appl. Bacteriol. 1992, 72, 445-459. [CrossRef] [PubMed]

57. Zohary, T. Hyperscums of the cyanobacterium Microcystis aeruginosa in a hypertrophic lake (Hartbeespoort Dam, South Africa). J. Plankton Res. 1985, 7, 399-409. [CrossRef]

58. Ueno, Y.; Nagata, S.; Tsutsumi, T.; Hasegawa, A.; Yoshida, F.; Suttajit, M.; Mebs, D.; Pütsch, M.; Vasconcelos, V. Survey of microcystins in environmental water by a highly sensitive immunoassay based on monoclonal antibody. Nat. Toxins 1996, 4, 271-276. [CrossRef]

59. Lopes, V.R.; Ramos, V.; Martins, A.; Sousa, M.; Welker, M.; Antunes, A.; Vasconcelos, V.M. Phylogenetic, chemical and morphological diversity of cyanobacteria from Portuguese temperate estuaries. Mar. Environ. Res. 2012, 73, 7-16. [CrossRef] [PubMed]

60. Frazao, B.; Martins, R.; Vasconcelos, V. Are known cyanotoxins involved in the toxicity of picoplanktonic and filamentous north atlantic marine cyanobacteria? Mar. Drugs 2010, 8, 1908-1919. [CrossRef] [PubMed]

61. Landsberg, J.H. The effects of harmful algal blooms on aquatic organisms. Rev. Fish. Sci. 2002, 10, 113-390. [CrossRef]

62. DeMott, W.R.; Moxter, F. Foraging cyanobacteria by copepods: Responses to chemical defense and resource abundance. Ecology 1991, 72, 1820-1834. [CrossRef]

63. Malbrouck, C.; Kestemont, P. Effects of microcystins on fish. Environ. Toxicol. Chem. 2006, 25, 72-86. [CrossRef] [PubMed]

64. Amorim, Á.; Vasconcelos, V.T. Dynamics of microcystins in the mussel Mytilus galloprovincialis. Toxicon 1999, 37, 1041-1052. [CrossRef]

65. Williams, D.E.; Dawe, S.C.; Kent, M.L.; Andersen, R.J.; Craig, M.; Holmes, C.F.B. Bioaccumulation and clearance of microcystins from salt water mussels, Mytilus edulis, and in vivo evidence for covalently bound microcystins in mussel tissues. Toxicon 1997, 35, 1617-1625. [CrossRef]

66. Vasconcelos, V.; Oliveira, S.; Teles, F.O. Impact of a toxic and a non-toxic strain of Microcystis aeruginosa on the crayfish Procambarus clarkii. Toxicon 2001, 39, 1461-1470. [CrossRef]

67. Zimba, P.V.; Camus, A.; Allen, E.H.; Burkholder, J.M. Co-occurrence of white shrimp, Litopenaeus vannamei, mortalities and microcystin toxin in a southeastern USA shrimp facility. Aquaculture 2006, 261, 1048-1055. [CrossRef]

68. Backer, L.; Carmichael, W.; Kirkpatrick, B.; Williams, C.; Irvin, M.; Zhou, Y.; Johnson, T.; Nierenberg, K.; Hill, V.; Kieszak, S.; et al. Recreational exposure to low concentrations of microcystins during an algal bloom in a small lake. Mar. Drugs 2008, 6, 389-406. [CrossRef] [PubMed]

69. De Silva, E.D.; Williams, D.E.; Andersen, R.J.; Klix, H.; Holmes, C.F.; Allen, T.M. Motuporin, a potent protein phosphatase inhibitor isolated from the Papua New Guinea sponge Theonella swinhoei Gray. Tetrahedron Lett. 1992, 33, 1561-1564. [CrossRef]

70. Rinehart, K.L.; Namikoshi, M.; Choi, B.W. Structure and biosynthesis of toxins from blue-green algae (cyanobacteria). J. Appl. Phycol. 1994, 6, 159-176. [CrossRef] 
71. Krishnamurthy, T.; Carmichael, W.W.; Sarver, E.W. Toxic peptides from freshwater cyanobacteria (blue-green algae). I. Isolation, purification and characterization of peptides from Microcystis aeruginosa and Anabaena flos-aquae. Toxicon 1986, 24, 865-873. [CrossRef]

72. Zhao, Y.; Shi, K.; Su, X.; Xie, L.; Yan, Y. Microcystin-lr induces dysfunction of insulin secretion in rat insulinoma (INS-1) cells: Implications for diabetes mellitus. J. Hazard. Mater. 2016, 314, 11-21. [CrossRef] [PubMed]

73. Strohalm, M.; Hassman, M.; Košata, B.; Kodíček, M. Mmass data miner: An open source alternative for mass spectrometric data analysis. Rapid Commun. Mass Spectrom. 2008, 22, 905-908. [CrossRef] [PubMed]

74. Strohalm, M.; Kavan, D.; Novák, P.; Volný, M.; Havlíček, V.R. Mmass 3: A cross-platform software environment for precise analysis of mass spectrometric data. Anal. Chem. 2010, 82, 4648-4651. [CrossRef] [PubMed]

(C) 2017 by the authors. Licensee MDPI, Basel, Switzerland. This article is an open access article distributed under the terms and conditions of the Creative Commons Attribution (CC BY) license (http:/ / creativecommons.org/licenses/by/4.0/). 